\title{
Voices of Canadian and Mexican Youth Surrounded by Violence: Learning Experiences for Peace-Building Citizenship ${ }^{1}$
}

\author{
Forthcoming 2016 in Research in Comparative International Education theme issue: Revisiting Peace Education: \\ Bridging Theory and Practice, edited by Zehavit Gross \\ Drafts presented at Comparative and International Education Society, March 2016, and \\ American Educational Research Association, April 2016
}

\author{
(C) by Kathy Bickmore, Yomna Awad and Angelica Radjenovic \\ Ontario Institute for Studies in Education, University of Toronto, Canada
}

\begin{abstract}
How do young people living in high-violence contexts express a sense of democratic agency and hope, and/or frustration and hopelessness, for handling various kinds of social and political conflict problems? The management of conflict is a core challenge and purpose of democracy, severely impeded by the isolation and distrust caused by violence. Publicly-funded schools can be (but often are not) part of the solution to such challenges (Bickmore, 2014; Davies, 2011). This paper is drawn from a larger on-going project probing the (mis)fit between young people's lived citizenship and conflict experiences, and their school-based opportunities to develop democratic peace building capacities, in non-affluent local contexts surrounded by violence, in international comparative perspective. We report on focus group conversations with several small groups of students, ages 10-15, in 2 Canadian and 4 Mexican schools in marginalized urban areas. Diverse participating young people tended to have a stronger sense of agency and hope in relation to some kinds of conflicts (such as environmental pollution) compared to others (such as unemployment and insecure work or drug-gang violence). In general, they did not feel that their lived citizenship knowledge was much valued or built upon in school.
\end{abstract}

Citizenship, peacebuilding, and the role of formal education in contributing to each are contested, malleable ideas shaped by cultural, political, economic and social factors. Formal education is a project of nationstates, thus citizenship and peace-related education in publicly-funded schools often emphasizes nationalist loyalty and compliance to dominant norms, perhaps especially in countries affected by armed conflict (Bush \& Saltarelli, 2000; Quaynor, 2012). Paradoxically, education is also associated with the development of democratic agency.

Democratic processes are conflict management processes - deliberative dialogue and collective decisionmaking in the face of difference, disagreement and ideological struggle. To flourish, democracy requires an adequate level of social peace, just as building and sustaining just peace requires democracy. Democratic processes and roles (including legislative, judicial and communitarian-dialogic) are designed to prevent or redress violence by equitably handling social-political conflicts. Although they are inextricably connected, conflict analysis distinguishes violence (harmful actions and effects) from the conflicts that underlie them (the disagreements, competing needs, and factors provoking or encouraging those actions), in order to focus on solvable problems more than symptoms. Beyond the presence or absence of direct violence, social conflicts have two crucial dimensions: social-structural concerns revolving around tangible interests (competing desires and needs, such as access to natural resources or economic opportunities), and psycho-cultural concerns embedded in beliefs, narratives, and interpretive elements of relationships such as (dis)trust or bias (Ross, 1993, 2010). Another dimension shaping the evolution of conflicts, crucial for democracy, is each (diverse) citizen's relationship with governance institutions and mechanisms that might help (or hinder) in the constructive transformation/ resolution of those conflicts.

The capacities to recognize conflicts and to comprehend contrasting viewpoints are learned through, and necessary for, democratic citizenship participation (Bickmore, 2008; Bickmore \& Parker, 2014). To practice conflict communication and problem-solving skills requires a certain amount of autonomous agency and opportunity, embodied in relatively democratic rather than authoritarian school and classroom practices.

\footnotetext{
${ }^{1}$ We gratefully acknowledge funding from the Social Sciences and Humanities Research Council of Canada. In addition to the authors, M. Patricia Carbajal, A. Salehin Kaderi, Angela Guerra, Diego Nieto, Paloma Ramirez, and Tanja Urbancic made valuable contributions to data collection and analysis. Drafts of this paper were presented at the Comparative and International Education Society (March 7, 2016) and American Educational Research Association (April 12, 2016).
} 
Democratic peace-building capabilities may be learned (or not) in formal classroom lessons, and they are also practiced and affirmed (or, over-ridden) on a daily basis in students' human interactions, within and beyond the school (Bickmore, 2011a, 2014). This is the problem at the center of our research: school initiatives for peacebuilding and citizenship education may connect to and build upon-or, unfortunately, they may ignore and contradict - the implicit peace-building citizenship learning embedded in young people's experiences, especially in marginalized communities. Where school-based education helps to nurture young people's agency for handling contrasting perspectives and conflicts in their own societies, it also nurtures hope (Freire, 1994; Werner, 1997, 2002).

In Canada, México, and around the world, typical school-based citizenship and peace-related programming generally has not succeeded in addressing widespread social and political disengagement, nor on-going patterns of interpersonal and larger-scale aggression and violence (Cox, Bascopé, Castillo, Miranda, \& Bonhomme, 2014; Daniel \& Bondy, 2008; Hughes, Print, \& Sears, 2010). There is an apparent mismatch between the citizenship curriculum usually taught in schools and the citizenship actually enacted and intended by many young people (e.g. Torney-Purta \& Amadeo, 2011). Similarly, the implicit citizenship socialization embedded in typical antiviolence efforts has been roundly critiqued as often harsh, inequitable and ineffective (Abrego, 2010; Aronson, 2000; Bickmore, 2011b; Skiba \& Peterson, 1999). In contrast, quality education for engaged democratic citizenship and peacebuilding depends upon recognition and discussion of students' existing understandings, experiences and concerns in relation to their social realities (Davies, 2005; Diazgranados \& Noonan, 2015; Morrison \& Vaandering, 2012; Tapia, 2003). School-based education can connect with diverse young people's lived understandings and can prepare them for democratic peacebuilding citizenship, but unfortunately typical schooling would need substantial change to live up to such hopes. The research reported here is intended to support such transformation.

This study young people's understandings and opportunities to learn about a key component of both democratic citizenship and peacebuilding: the causes of social conflict and violence problems and the actions possible to mitigate them. (Other aspects of the project assess the responsiveness of school-based learning opportunities to those understandings, and examine teachers' innovation leadership to improve those learning opportunities.) To maximize contrast among the types of conflict with which learners may be concerned, and among the types of relevant educational programming, research sites are purposively chosen upper elementary and intermediate public schools in urban Canada and México, in which educators have expressed interest in improving their practices in relation to citizenship and/or peace-building.

México and Canada are both imperfect democratic systems experiencing widespread current concern about aggression, lethal violence, citizen engagement, and social inequalities involving youth. However, serious violence - including gender-based violence and gang activity — is substantially more pervasive in México (IEP, 2015; Pearce, 2010; Peetz, 2011). Unfortunately, in both countries, typical school anti-violence and citizenship education practices emphasize transmission and control, leaving little room for responsiveness to diverse and socially marginalized students' lived experiences and concerns (research cited below). This qualitative, international comparative research is designed to examine the interactions among school-based participants and specific social conflict concerns in differing environments facing violence.

\section{Feet-first learning for peacebuilding-related citizenship}

We assume that many peace-building-relevant citizenship understandings, attitudes and skills are learned "feet first" (through modeling, reinforcement and practice embedded in lived experience). Typical "hearts and minds" approaches to peace-building citizenship education, in contrast, attempt to inform and motivate belief change, in order to create attitude change, in turn to promote behaviour change: there is little convincing evidence that hearts and minds approaches to peacebuilding, such as inter-group prejudice reduction, sustainably achieve their goals (McCauley, 2002). Feet first, small changes in behaviour can open the way for further change and learning; behaviour that is supported within a social context tends to be repeated (ibid). When people find themselves acting in ways dissonant with prior beliefs, they may change their beliefs to make sense of their behaviour, which in turn may make them open to further behaviour in line with the new beliefs (Festinger, 1964). Explicit lessons and implicit practices in public schools may build upon—or contradict—students' experiential knowledge rooted in their particular community contexts.

Political psychologist Richard Merelman (1990) theorized that children growing up in highly contested or violent contexts would tend to learn (through feet-first experience) different concepts and skills about conflict (and consequently about democracy and peace) compared with children growing up in relatively peaceful regimes 
in which conflict and dissent were less visible and less normalized. While both contexts would 'teach' knowledge of value for peacebuilding, schooling would face different gaps: in relatively peaceful contexts, young people might need to learn to recognize and consider (not marginalize) divergent voices in social and political conflicts; in contested, insecure contexts where conflicts were more obvious, young people might need to learn to engage communicatively and nonviolently across those axes of difference. Thus this comparative study examines young people's lived understandings of conflicts, potentially linked to implemented curriculum, in contrasting contexts.

Most approaches to peace/conflict resolution education are "head first" and "prescriptive," assuming the superiority of Western (global Northern) expert knowledge and ignoring the lived concerns and understandings embedded in the language and heritage of any community (Lederach, 2003). Western neoliberal educational ideas have spread around the world, creating remarkable similarities among the guiding ideas in recent citizenship as well as peace/conflict education curricula, despite enormous differences in social realities such as cultural roles and levels of violence (Meyer, Bromley, \& Ramirez, 2010; Salomon \& Nevo, 2002; Suárez, 2008). In contrast, Lederach (1995) argues for democratic peace-building education to "elicit" and build upon implicit (feet-first, deep-cultural) knowledge, because politically- or culturally-irrelevant prescriptions are unlikely to be workable, fair, or sustainable. Thus this research was designed to encourage teachers and students to name, reflect, and build upon the peace-building citizenship understandings and concerns they had been enacting already in their lives.

Explicit implemented citizenship curriculum in Canadian schools tends to emphasize formal structures for participation; in contrast, young people often do not express much interest in such formal political participation, and instead favor direct engagement to address problems of personal interest (Hughes \& Sears, 2008).

Troublingly, students in recent research repeated mainstream citizenship notions taught in school (such as the importance of voting), yet made clear that they did not intend to act accordingly (Chareka \& Sears, 2006). They typically equated good citizenship not with governance or politics much less dissent or social action, but with being a good person on an individual level, such as assisting the elderly, environmental care, or charitable aid (Chareka \& Sears, 2005; Llewellyn \& Westheimer, 2009). Racially and economically marginalized youth, while repeating similar dominant narratives, also expressed a contradictory "power-blind" sense that many people like themselves were undeserving and at fault for their own marginalization (Kennelly \& Dillabough, 2008; Tupper \& Cappello, 2012; Tupper, Cappello, \& Sevigny, 2010). Evidently, the lived citizenship experiences of Canadian students, especially racialized and economically marginalized youth, are often at odds with the usual messages in school citizenship education.

Perhaps even more so than in Canada, most citizenship education in México involves lecture pedagogy and passive learner roles (Acevedo Rodrigo \& López Caballero, 2012; Andere, 2013; Reimers \& Villegas-Reimers, 2006). In Mexican and other Latin American schools, institutional pressure to transmit large amounts of information often "prevents inclusion of the students' experience and imposes contexts that relate exclusively to students from upper (or upper middle) class backgrounds" (Tibbitts \& Torney-Purta, 1999, p. 17). Yet, there exist in México some exemplary democratic education initiatives, including some in public schools (Farrell, Manion, \& Rincón-Gallardo, forthcoming 2017; Rincón-Gallardo \& Elmore, 2012; Santizo Rodall \& Martin, 2009). Critical dialogic pedagogy models originating in Latin America have been implemented in schools around the world (Bartlett, 2005). Recent Mexican curriculum reforms to support participatory citizenship and peaceful coexistence include a new Civics and Ethics course beginning in 1999 (Ornelas, 2013; Reimers, Ortega, Cardenas, Estrada, \& Garza, 2014).

In recent surveys, Mexican youth generally expressed disinterest, distrust, and lack of knowledge about formal politics; they reported participating in civic organizations or political parties less frequently than, for example, Chilean and Colombian youth (Reimers \& Cardenas, 2010). Majorities said that citizens had little influence over politicians and big business. Secondary school students showed little understanding of democratic ideas such as popularly elected representation or equitable involvement of women in politics (Guevara \& Tirado, 2006). While many or most Mexican youth surveyed were disengaged from formal politics, most had engaged in "private solidarity" such as aid contributions after natural disasters, and about a quarter had volunteered in their communities (op cit).

México is undergoing a period of escalated violence. Due to pressures such as out-migration and drug trafficking, the situation in the central Mexican state where our research takes place has deteriorated markedly in the past dozen years: the number of crime victims in Guanajuato increased by about $50 \%$ between 2010 and 2014 (IEP, 2015). In one México-wide survey, "about $20 \%$ of students described the school they last attended as a place where there was some or much violence among classmates" (Reimers \& Cardenas, 2010, p. 154). However, those youth generally described their schools as somewhat supportive of democratic tolerance and participation. 


\section{Young people's understandings of social conflict and the potential impact of pedagogy}

Few prior studies have examined young people's understandings of social conflict in their societies, especially in relation to their sense of hope and/or perspectives on potential democratic agency in response to those conflicts. A review of citizenship education research in conflict zones around the world (Quaynor, 2012) shows that formal school curriculum tends to avoid addressing sensitive issues, and either to avoid recognizing ethnic group differences or to highlight them in an ethnocentric manner. In some contexts examined, many students wished for more opportunity to learn about, discuss, and engage with the conflictual questions around them. As in México, these students often expressed distrust of formal political parties and systems, and (yet) some tended to value the apparent security of authoritarianism (ibid).

Lived citizenship - idiosyncratic to each location, time, and cultural context - is the nexus of young people's social learning of democracy, conflict management and citizenship roles, as well as their potential development of democratic agency.

The everyday environments that are meaningful to children and young people differ greatly from those where their participatory agencies are institutionally supported. ... [Young people's] relations with issues such as ethnicity and race, gender and sexuality, affluence and neediness, environmental issues, or any major feature of their societies, are formed through ... their political subjectivities and understandings about the world as a political context. Therefore also the matters that concern them in which they like to be heard, about which they have self-governing opinions, and for or against which they may want to act - vary (Kallio, Häkli, \& Bäcklund, 2015, pp. 111, 113).

Many young people's subjective experiences have taught them a great deal about conflict, but include cynicism or despair regarding the possibilities for peaceful, just, democratic social relations and governance (Bellino, 2015; Ridley \& Fulop, 2015). For instance, focus group interviews with youth, ages 14-24, in a post-Soviet Georgia conflict zone demonstrated participants' clear understanding of "conflict" as violent or nonviolent "confrontation between two or more sides" (p.79). All showed emotional engagement and could distinguish among types of conflicts, from interpersonal through inter-state. The same youth defined "tolerance" in terms of successful management of conflict: humane treatment, respect, good relationships and accommodation of difference (p.8384). They did not express hope for successful establishment of tolerant relationships in large-scale public governance conflicts. Similarly, a study of Lebanese higher education students' creative writing suggests that most of these young people felt hopeless about the environment of escalating hostility and intolerance in which they were living (Khalaf, 2014). Clearly, such lack of hope presents a pressing problem for democratic engagement.

A South African study showed that most participating higher education and upper secondary students preferred to avoid discussing difficult historically-embedded conflicts, and/or to avoid criticality in such discussions, although the authors considered it feasible to create safer learning contexts for such democratic conflict (Costandius \& Bitzer, 2014). In contrast, a study of forty adolescents in Northern Ireland (Barton \& McCully, 2005) showed young people who were comfortable with the persistence of competing narratives, who drew understandings from community traditions more complex than mere Unionist (Protestant) or Nationalist (Catholic) binary positions. Participants of all backgrounds emphasized the importance of community conflict and remembrance; Catholics (the less powerful party in this conflict) also emphasized fairness and equal rights. Evidently some contexts, more than others, support constructive communication about conflicts.

Young people's lived experience - including at times colonial relations and human rights violationsevidently influence what social conflicts they understand and consider important. Task-based interviews with 116 students in Colombia, Northern Ireland, the Republic of Ireland and the United States demonstrated participants' awareness of global, national, and local human rights issues, and the differential salience of these issues to various students depending on national discursive contexts, school instruction, and personal experience (Barton, 2015). Discussion-based inquiry with ten students in one integrated, justice-oriented English high school (Keddie, 2014) showed that participating young people were well aware of inter-religious conflicts and biases in their society, but they viewed religious identities as socially constructed and contingent, and considered themselves to be supportive of religious diversity. Another exploratory study, in Ontario, Canada, showed that participating high school students were emotionally affected by events surrounding the September 2001 terrorist attacks on the USA, and that they had developed some historical understanding of the social conflict roots of terrorism (Levesque, 2003). However, prevailing biased narratives, as well as direct experience, clearly influence young people. For instance, 
a study of Australian primary students' understandings of the possibilities for inter-group reconciliation with aboriginal people found that, "Racialisation was the prism through which students understood and experienced others' and their own social and political position" (Aberdeen \& Mariko Matthews, 1999, p. 215). Although the children expressed abstract beliefs in tolerance, equality and justice, these beliefs coexisted with inaccurate, ethnocentric ideas.

In a comparatively peaceful settler society, 24 Canadian high school students in small groups analyzed primary source documents to interpret an historical conflict case: the decision of the small Ontario city of Berlin to change its name to Kitchener in 1916, because then-prevailing narrative framed Germany as enemy (Seixas, Peck, \& Poyntz, 2011). Like the students in the Georgia conflict zone, these students showed no difficulty discerning the conflicting perspectives and impacts felt by proponents and opponents of the change. They sometimes betrayed confusion about what actors or institutions would have the authority to make decisions around such conflict. They linked this historical conflict with current events (including the then-on-going war in Iraq). Students' own ethno-cultural identities apparently influenced their understandings of issues such as bias against minority newcomer immigrant groups - sometimes trumping historical evidence. The focus group discussions as learning opportunities demonstrated that carefully planned conflictual material could elicit expression of conflict knowledge.

Having established that young people in contrasting social contexts can understand the anatomy of various conflicts - clashing perspectives and choices that may escalate or de-escalate and that demand decision makingwe turn our attention to the potential role of schooling in supporting (or not) young people's development of capacity and inclination to participate in democratic decision-making in response to social conflicts. Robust international evidence indicates that when students report having had opportunities for discussion of conflicting perspectives in an open, inclusive classroom climate, they tend to have both better understanding of democratic questions and processes and higher interest in democratic participation, compared with students who have not had much such experience (Kahne \& Sporte, 2008; Schulz, Ainley, Fraillon, Kerr, \& Losito, 2010; Schulz, Ainley, Friedman, \& Lietz, 2011; Torney-Purta \& Amadeo, 2011). For instance, grade 8 students, in one Liberian armed conflict context in which texts did explicitly address past injustices, expressed emotional engagement, critique, and complex understanding of how democratic political rights were limited by economic marginalization and government corruption (Quaynor, 2014). College students who had participated in a series of facilitated intergroup dialogues about justice issues in a fourteen-week course (compared to peers) demonstrated more positive beliefs about cross-group interactions and the value of addressing conflict, and more political interest and community participation, even four years after the course (Nagda \& Gurin, 2007). Thus, schooling can intersect with and democratize students' lived citizenship experiences.

Similarly, some peacebuilding education research suggests that open classroom presentation and discussion of conflicting perspectives encourages both emotional engagement and cognitive sophistication in understanding the democratic challenges of social conflicts. For instance, discussions among 75 Jewish and 80 Palestinian Israeli youth age 16-18, in four groups (Goldberg \& Ron, 2013), used three different approaches to teaching the history of that country's refugee conflict (plus a control group that received only the usual history education of their segregated school systems). The two groups that participated in history lessons addressing multiple perspectives ("critical disciplinary" or "empathetic dual narrative"), compared to the group that received only a traditional single narrative and the control group, engaged in discussions that were considerably more extended and less confrontational in tone. Further, the Jewish youth in those groups acknowledged Jewish responsibility for the onset of the refugee conflict, and students from both groups proposed understandings and solutions that recognized the suffering of each Other and expressed a sense of reciprocity. High-quality, participatory interpersonal conflict resolution education, extra curricular or infused in academic curriculum, similarly has been shown to increase participants' capacity and inclination to discuss and handle conflicts nonviolently (Bickmore, 2002, forthcoming 2017; Diazgranados, 2014; Harris, 2005; Jones, 2004). Thus, opportunities for young people to recognize and discuss conflicting narratives and perspectives in a humanizing climate apparently encourage development of capacities and inclinations for engaged, nonviolent peace-building dialogue. Although it can constitute part of the problem, school curriculum and pedagogy evidently can constitute part of a peacebuilding citizenship solution. The first step in developing culturally and contextually appropriate education is to elicit young people's lived understandings and concerns. 


\section{Research Design and Methodology}

International cross-cultural comparison is valuable to disentangle the threads of possibility and challenge in peace-building citizenship education, as experienced in particular contexts (Tobin, 1999). To maximize variation in the social conflict and violence problems of primary concern to youth participants, and the cultural, political, and pedagogical contexts for addressing them, the project purposively selected three public schools in southcentral Canada (Ontario), and four in central México (Guanajuato). This paper reports on two of the Ontario schools (grades 5-6 in one, 5-8 in the other) and three of the Guanajuato schools (two elementary, focusing on grades 5-6, and one intermediate, grades 7-9). Analysis of data from remaining Canadian and Mexican schools, and four schools in Bangladesh, is continuing. The focus is on 10-15 year olds - an age at which violence is a challenge, yet most youth are still in school. The major criteria for school selection were location in differing violent surroundings, and that several teaching staff expressed interest in working to improve the relevance and effectiveness of their peace-building and/or citizenship education work. Within each school, the research engaged 4-5 teachers, and at least 15 upper elementary or intermediate grades students (in small groups) from their classes. The over-all research plan was to work with teacher and student participants to identify social conflict situations that concerned them, to elicit students' experiential understandings of those conflicts and what citizens could do about them. Next, we juxtaposed those understandings with prescribed and implemented curricula in each context, to provoke re-thinking of pedagogical practices to build upon and respond to those understandings and concerns. This paper reports and discusses the findings from these student focus groups in two Canadian (Ontario) and three Mexican (Guanajuato) schools.

After background work (recruiting schools and participants, analyzing curriculum mandates and contexts), the first research stage (summarized only briefly below) involved a series of two (90 minute) focus group discussions with teacher participants in each school. As an elicitive needs assessment baseline, the teachers were invited to describe their existing beliefs and pedagogical practices in relation to citizenship, social conflict and violence. Second, they chose and discussed a set of images (photos and cartoons) representing local and larger-scale social conflict and violence problems that they considered relevant to diverse students in their particular school community, for the researchers to use as prompts in focus groups with the students.

The second stage, reported on in this paper, involved one (60-70 minute) focus group discussion workshop each with 3-4 groups of about 5 students per school - animated by the visual prompts vetted by their teachers. The idea was to prompt conversation about concrete instances of social conflict and violence - to elicit the social conflict problems of primary concern to these young people, discern how they understood their causes and the actions citizens like themselves could take to mitigate them, and then to examine how these students viewed existing school lessons and practices as (ir)relevant to those concerns. The final stage (in progress) involves leadership development with the same teacher focus groups, based on anonymized interim results, concurrent with further data analysis.

Qualitative data analysis has followed a modified grounded theory approach (Charmaz, 2000), meaning that each round of interpretations has informed further data collection and analysis. Analysis to answer the first research question, reported in this paper, describes participating students' understandings of various kinds of social conflict and violence, their causes, and the potential government or citizen actions that may help to mitigate them-linked to their experiences in and outside of their schools. An analytical rubric to synthesize and make sense of participants' understandings, initially derived from the literature and frequently revised based on data analysis, examines how participants discerned multiple points of view, how they distinguished violence from the conflicts that underlie and cause it, and their sense of agency or hope(lessness) for citizenship participation in addressing such problems. Near the end of this paper, we briefly compare the students' conceptions and concerns to their perspectives on the curricula taught to them in school.

This research design is exploratory, limited, and not generalizable. A sample of students and teachers in each school chose to speak about some of the concerns they knew about, constrained by time limits in focus group workshops. They were more likely to speak about conflicts for which the research team provided image prompts: although we selected and vetted the set with teachers to match each local context, presumably other student concerns were not elicited in these conversations. On the other hand, the method combines inquiry with joint learning and action, right at school sites, eliciting local knowledge that will later be applied to facilitate codevelopment of locally relevant teaching resources. It will be important to continue investigating in different types of conflict (and peace) zones, and to further investigate teacher professional development principles, in order to find possible windows for infusion of student-relevant democratic peacebuilding education in schooling. 


\section{Findings}

In our iterative data analysis process, the research team categorized various types of social conflict, in order to compare/contrast study participants' understandings, concerns, and sense of capacity in differing domains of citizenship and conflict experience. Following Marc Howard Ross (cited above), we categorized some conflicts that participants discussed as primarily intangible, psycho-cultural in nature (particularly dehumanizing beliefs that sometimes legitimized direct violence, such as gender-based abuse), and conflicts primarily reflecting competing socially structured, tangible interests such as environmental degradation and economic inequality. Another category was direct violence itself, in interpersonal and community relations - bullying, fighting, and gang territorial aggression. In this instance, our study participants saw the violence itself (not its underlying causes) as the problem. One further category of conflicts that emerged as a major concern of many participants, that again did not fit neatly into Ross' (social-structural or psycho-cultural) categories, was the corruption, abuse of power, and ineffectiveness of government agents and institutions (especially police) ostensibly charged with facilitating democratic peacekeeping (security), peacemaking (negotiated decision making), and/or peacebuilding (deep-structure problem solving for justice).

Below, we present young people's understandings about social conflicts that were of particular concern to them in both cities (in Mexico and Canada), in each of the above categories. These are: economic inequality conflicts (including poverty and homelessness, labour exploitation, unemployment, and drug trafficking), pollution and environmental conflicts, interpersonal and community aggression involving students themselves, domestic and gender-based violence, and government/police abuse of power. In brief, the student focus group data show strong concern about transnational and local social conflict and violence (in the Mexican sites especially, inundation in violence without confidence in social institutions that might help to handle it), strong desire to know more about how to understand and handle conflicts, and some confusion about the anatomy of conflict (parties and their interests, roles of social institutions, distinction of violence from underlying conflicts).

\section{Conflicts about tangible social-structural interests (A): economic inequality problems}

Notable in the students' discussions of economic inequality conflicts, in both countries, was their sense of no or severely limited agency. Poverty (often framed as homelessness in Ontario), linked to unemployment and labor exploitation, was a strongly felt concern for students in all three Guanajuato schools, and in one Ontario school more than the other. All recognized that discrimination (against women, indigenous people, people from poor neighborhoods, or visible minority immigrants, depending on the setting) exacerbated this problem. In all five schools, more in Guanajuato than in Ontario, some students told vivid stories that indicated close-up experience with poverty. Students recognized the actors in this conflict as greedy individuals (bosses), ineffective government (welfare, job creation, or regulation), and occasionally poor people themselves. Those who had firsthand experience tended to humanize poor people and to direct the blame elsewhere, whereas some peers partly blamed poor people for their misfortunes (calling them lazy, drug addicted, and/or uneducated). In Ontario, one or two students mentioned minimum wage; otherwise, students in no school showed awareness of any social or political institutions, collective actors, or processes that could shape or mitigate poverty problems. Students in both communities expressed a sense of injustice about economic inequalities, mentioning political protest in two Guanajuato schools. A few in each settings, especially in Guanajuato, expressed a dominant narrative (hope) that one could avoid poverty by working hard and getting educated. In Ontario, a small number of girls mentioned charity assistance. Otherwise, students in neither community expressed hope for change, beyond individual coping to surmount obstacles. As one Guanajuato student expressed the prevailing view, poverty and economic inequality were inevitable: just "get used to it."

In all three Guanajuato schools, out-migration was an economically linked local problem: a major concern to students was their sense of abandonment and economic stagnation, because many of their parents, relatives and community members had felt compelled to migrate (legally and illegally) to the USA (or Canada), due the scarcity of secure, adequately-paid employment at home. In the two Ontario schools, a less vivid but very evident concern was the prevalence of bias against in-coming migrants, exacerbated by perceived competition for jobs and government support (such as contested health care funding for refugees). Either the out-migration conflict or the bias against incoming immigrants had been discussed somewhat in some classrooms in all five schools. Students in all schools (especially in Guanajuato) recognized economic need as a driver and a cause of suffering. In two Guanajuato schools, students argued (without evident hope) that their government should do more to create jobs, to reduce the incentives for out-migration.

In Guanajuato, a prominent and very painful social response to economic conflict was drug trafficking, which 
was associated with violent gang activity and intense insecurity in the neighborhoods of all three participating schools. Drug trafficking was not mentioned as a main concern in Ontario. Students in all three Guanajuato schools understood drug trafficking to be a consequence of poverty and exploitation, exacerbated by government corruption, collusion, and ineffectiveness. While a few students in two of those schools expressed a wish that the government would do something to mitigate drug trafficking, all Guanajuato students seemed to feel especially hopeless about this, and most viewed the authorities as part of the problem.

In sum, all participating students in both urban communities recognized poverty, migration, drug trafficking, and other economic inequality as power-imbalanced conflicts. Most had no trouble identifying (and, especially in México, identifying with) the points of view of those gravely harmed by exploitation, marginalization, and the drug trade. Although they knew a lot about the conflicts' symptoms, very few students in any of the settings recognized actors (beyond locally visible business owners or gang kingpins) or exacerbating political or socialstructural factors, nor did they show awareness of any particular government or civil society processes that could contribute to constructive conflict transformation. Such an information gap presumably would impede participation in effective democratic action. Thus in general, the students' lived experience made some of them skeptical of dominant narratives about the causes of economic suffering (or success), but did not help them to create alternative narratives. Virtually all expressed despair about any collective action to mitigate such conflicts.

\section{Conflicts about tangible social-structural interests (B): Pollution and environmental degradation}

Pollution represents another kind of tangible social interest conflict, which participants did not link to economic inequality. Many viewed this issue as less sensitive than most other social conflicts discussed, perhaps because of the way they viewed the problem and the absence (in their conversations) of any large-scale proposal for mitigation or transformation. The pollution concern was felt intensely by students (expressing frustration, sadness, and outrage) in the three Guanajuato schools, because air, water, and land (dumping) contamination were very evident in their communities.

In contrast, students in Ontario expressed concern about environmental threats (such as pipelines or global climate change), but generally framed the problems as relatively abstract, distant from their experience: they did not choose to discuss pollution much in the focus groups. Several Ontario students (and very few in Guanajuato) showed a general awareness of global climate change, and/or confirmed that they had learned about oil pipelines one day in class, but did not raise or discuss any (individual or social-political) proposals or solutions for mitigating environmental conflicts.

Guanajuato students blamed local river pollution primarily on individuals who dumped garbage and dead animals. When facilitators probed, most also identified as polluters local factories, such as tanneries. One or two in a few focus groups added a political dimension - that the government offered inadequate garbage collection, treatment, or regulation. Students in all the Guanajuato schools suggested, as responses to pollution conflicts, only individual actions such as not littering, picking up trash, recycling, riding bicycles instead of driving (very few of their families owned cars), consuming less plastic (nobody suggested any alternative, such as bottle deposits or packaging regulations; plastic garbage was ubiquitous in all five school communities). In one school, students proposed putting up posters to urge people not to pollute - a collective action, although not confronting the roots or major actors in pollution problems. Larger-scale actors and polluters disappeared from the conversation when facilitators asked about actions that might help solve the problem. The Guanajuato youths' suggestions for (individual) environmental efforts sounded so similar to one another, and so distanced from their lived experience, that we assume they came from a textbook lesson.

In sum, the young people in all five communities showed awareness and (varying degrees of) unhappiness and/or anger about environmental pollution, and viewed themselves among as its victims. Students in the Ontario schools showed some awareness (apparently derived from news sources and a few classroom lessons) of recent scientific-political debates about oil pipelines and/or climate change. However, they showed little understanding of particular parties to the conflict, their social-economic interests, or their proposals for actually addressing the problems, and they didn't show much interest in discussing these matters. Students in the Guanajuato schools, despite their intense feelings about the escalated severity of environmental problems, spoke about pollution as primarily a matter of selfish or careless individual choices - proposing incremental individual behaviour change but showing no awareness of any larger effort, governance mechanism, or proposal to transform or mitigate major environmental problems in their immediate vicinities. Thus environmental conflicts were addressed only in noncontroversial ways in each community, and not as political or scientific/ technological conflicts to which democratic actors could propose solutions. 


\section{Conflicts (violence) fueled by psycho-cultural bias: Gender-based and domestic violence}

Students in all five schools recognized the problem of gendered and domestic violence as men and boys disproportionately harming women and children. In all schools, students named underlying cultural beliefs and patterns - sexism and male dominance ('machismo' in México) - clearly recognizing the social power/ harm imbalance distinguishing gender-based aggression. All students had directly experienced or heard about gendered and domestic violence. In all schools, some students disclosed vivid personal stories, indicating close encounters and preoccupation with problems such as sexual harassment, wife beating, rape, and child abuse.

Quite a few blamed individuals (such as bad men when they got drunk) as the causes of domestic aggression. Occasionally, mostly among some of the boys, women were also faulted for provoking or for not resisting to protect themselves or their children. A few Ontario students considered gender-based violence to be more of a problem in 'Other' (recent immigrant) cultures than in their own. On the other hand, students in both cities showed awareness of sexism in public media and advertising. Many, especially in México (where again students seemed to be repeating classroom lessons), also described generational cycles of modeling in the home as perpetuating male aggression. Thus they understood gender-based disrespect and violence in collective as well as personal terms.

Few Ontario students, and no students in these Guanajuato schools, were aware of any advocacy organizations, shelters, or support services for families or individuals experiencing violence. The only mention of any government actor was to suggest police/jail enforcement_-indicating, as with the students' responses to environmental conflicts, attention to controlling individuals rather than to transforming the culturally systemic factors they had recognized earlier. Especially in Guanajuato, several students suggested that citizens could report incidents to the police, but peers in the same focus groups always replied that that police would not come or couldn't do anything. Several students in both cities did express hope that education could enhance gender equity and consciousness about gender-based violence: however, essentially no participating student described having experienced any such education. While all were vividly aware of this type of violent social conflict, their repertoires of potential responses were very limited, tending to bypass collective or governance action for prevention.

\section{Interpersonal aggression conflicts in students' communities and schools}

In one Guanajuato elementary school and in both Ontario schools, students clearly worried about bullying in and around their schools. Students recognized that power differentials (often based in social identities such as-in Ontario - being a racialized minority newcomer) often exacerbated patterns of interpersonal aggression. Ontario students said that bullying happened "everywhere." Two students told personal stories about the risk of suicide by targets of bullying. In Ontario school T2, one student expressed media-fueled fear of future bullying: "sometimes bullying in high school could lead up to suicide ... that happens a lot... I am scared to go to high school." Ontario students also worried, to varying degrees, about cyber-bullying.

Whereas students in three of five schools worried about school-based aggression, students at all three Guanajuato schools told vivid personal stories indicating their frequent, sometimes traumatic experiences as victims and witnesses of severe direct violence, including armed violence and intimidation surrounding gang territories - more often in their neighborhoods and around the school areas than inside their schools. In contrast, Ontario students spoke very little about violence or insecurity on the street.

Students in all five schools had difficulty describing the conflicts underlying individual aggression — what people were fighting about. They emphasized only individual actions as alternatives to interpersonal aggression, but those actions addressed the violent behaviour, not the disputes or frustrations that might have motivated it. Most commonly expressed, even in relation to Guanajuato street violence, were notions of individual responsibility and appropriate behaviour (choosing not to hurt people). The second most common suggestion was to denounce perpetrators to authorities. Students in Guanajuato in relation to street violence, and in Ontario in relation to school aggression, argued for increasing surveillance, enforcement, and punitive measures to minimize direct violence. However, students in every group also expressed fear of reporting and skepticism that enforcement would be effective. Parallel to Guanajuato students' expressed dissatisfaction with law enforcement in relation to violent crime in their neighborhoods, Ontario students expressed dissatisfaction with how teachers and school administrators dealt with bullying inside their schools.

Students in both cities spoke passionately about the frequency of direct interpersonal violence in their lives. A few in some groups suggested that formal and informal education, such as 'stop the violence' campaigns, 
could make people more conscious and responsible. In Ontario school T2, students wanted opportunities to discuss interpersonal conflict, violence, bullying, and prevent strategies. They wished that "teachers could be more involved with the things happening," to step in and help to resolve issues. Very few students in any of the five schools discussed their own roles (except as victims), or the disputes or social contexts that might provoke aggression: they described violent symptoms and painful consequences, not the possibility to (learn to) nonviolently resolve legitimate disagreements. Conflict resolution through horizontal communication (a key ingredient of democracy as well as peace in miniature) was apparently absent from students' consciousness, throughout our sample and especially in the Guanajuato schools.

\section{Government (police) abuse of power, corruption and ineffectiveness}

All students in all Guanajuato schools, and in Ontario (especially T1), expressed concern about police brutality, disproportionately toward Black people (in Ontario) or poor people (in Guanajuato). Students in all focus groups in all Guanajuato schools had directly, repeatedly experienced police harassment and ineffectiveness. Several students in all these schools told vivid stories of police corruption and abusive behaviour in their communities. Students across Guanajuato, especially in school L1, also shared experiences with perceived ineffectiveness or unwillingness of law enforcement to mitigate violent activity in their neighborhoods. They believed that police were especially harsh and biased against people in their poor neighborhoods, argued that the government allowed police corruption to occur, and expressed profound alienation and mistrust. The majority of Guanajuato students recognized that corruption was rampant among government officials and police, who cooperated with drug traffickers, exacerbating insecurity in their communities and causing despair about finding solutions. Ontario students were concerned about bias-based aggression by some police, while Guanajuato students were concerned about bias-based aggression by many police, and further about corruption and ineffectiveness in police and the government in general.

All Ontario focus group participants were were familiar with (and outraged by) news media stories of racist profiling and aggression by police. Only some of these students, especially visible minority males in school T1, also had directly experienced disproportionate police harassment. Like the Guanajuato students, Ontario students understood cultural bias (in this context, usually racism or Islamophobia) as an aggravator of police brutality. Students in T1 expressed diverse views. Some said, "We can't just put all blame on government;" others argued that police bias and violence happened "more often than people think." Students in Ontario (elementary-intermediate) school T2 did not express particular confidence in government or police, but did not show the same degree of concern or discuss the issue in detail compared with T1 and the Guanajuato schools.

Most Guanajuato students viewed the government as making the problem of police aggression and corruption worse. Clearly this sense of hopelessness (and the facts on which it is based) limit possibilities for democratic peacebuilding or engagement. Even in Ontario, almost no students showed awareness of any way that government action could reduce police bias and aggression (one boy did mention racial equality laws). On the other hand, they did not generally extend their distrust from police to government in general.

\section{How did students' lived citizenship experiences intersect with implemented curriculum (teaching)?}

In summary, among the participating Ontario and Guanajuato students, we found some differences in degree, and a couple of differences in the conflict issues that were of most concern, but we also found a remarkable amount of commonality among their perspectives, understandings and concerns. In all five stressed communities, young people had learned feet-first to recognize a range of sensitive and difficult social conflict issues, including tangible social-structural problems such as environmental damage and economic inequality, and relatively intangible, culturally-rooted conflicts such as the machismo underlying gender-based violence. The students confirmed, in each neighborhood in both cities, their exposure to escalated direct violence in their immediate communities, and its terrible consequences in insecurity, limiting access to democratic space, and distrust of authorities. However, they did not seem to have accessed, through lived experience or through schooling, much understanding of how collective social and cultural institutions and actors had caused or exacerbated, or how they might help to mitigate, such conflicts. This left many of the young people feeling quite alienated, especially from formal democratic processes, and distinctly unhopeful about their own roles in democratic peacebuilding.

The research team collected two sources of evidence about the learning opportunities that had been provided to participating young people in these five schools (in addition to official curriculum documents in each context), in order to assess the (mis)match between this school education and the understandings and concerns (summarized 
above) that the students had derived from lived experience. Students: Near the end of the student focus groups, facilitators asked them what learning opportunities they had had in school to learn or develop skills related to the issues they had discussed, and also invited them to express their wishes and suggestions for school-based learning (to be delivered anonymously to their teachers). Teachers: In their own focus groups, teachers shared their own teaching examples and the ways they understood conflict issues and peace processes in their contexts. While thorough presentation of teacher focus group findings is beyond the scope of this paper, brief highlights of what we learned are presented below.

In all five schools, most participating teachers showed and told us that they emphasized teaching/practice to avoid conflicts, by making proper individual choices. Teachers' discourse in Ontario referenced "character;" in Guanajuato it was "values." Their primary strategy was not to teach skills or concepts for taking action toward resolving or transforming conflict, but to instill values such as respect and responsibility for self and others, respect for authority, self-regulation, kindness, cooperation, tolerance, and mutual support. A teacher at Guanajuato elementary school L2 said she taught honesty as a way to reduce corruption in society. Another teacher there guided students to reflect on personal choices, by listing in one column things that made them angry, and in the next column things that they could do to calm down and control themselves (not to address the problems causing their anger). Two teachers at L3 said they pointed to particular values on wall posters when correcting students' behaviour in disruption or conflict situations. Many teachers in the Ontario schools emphasized a similar approach they called character education — including much of the above, plus more emphasis on single individuals "making a difference" for "social justice." Several Ontario teachers, especially at school T1, taught about exemplary justice activists such as South African leader Nelson Mandela, Pakistani gender equity and education advocate Malala Yousafsai, and Canadian cancer research funding activist Terry Fox, as role models to inspire students to make their world better through individual actions. In both cities, teachers exhibited remarkable love and care for their students, for instance (especially in Guanajuato) using personal resources to ensure that all students had food or school clothing, although they did not necessarily hold high academic or active citizenship expectations for these children. Thus the most prevalent response to conflict in these schools was to model and teach individual "responsibility" in the form of conflict avoidance, self-control, compliance with rules, and an ethic of caring.

Most participating teachers occasionally taught or required students to practice some elements of constructive communication: self expression, listening, showing respect for alternative views. Some - more frequently in Ontario-also taught some procedures for interpersonal peacemaking: ground rules, explaining points of view, suggesting solutions. Some teachers explicitly modeled dialogic conflict resolution by mediating student disputes privately or in class circles. Others occasionally encouraged disputing students to talk out their problems autonomously, in lieu of punishing or arbitrating. During a "peace week" at Guanajuato school L3, one teacher had students write letters to a classmate with whom they had conflict, expressing their feelings and suggesting solutions. Most classrooms in both cities engaged students frequently in cooperative group work, thus encouraging (though usually not teaching strategies for) cooperation. Thus some teachers taught some peacemaking elements, usually unsystematically as issues arose. None of these schools had any explicit conflict resolution, mediation or restorative justice programming in place, to teach and/or facilitate non-punitive democratic peacemaking.

Teachers described just a few lessons (not in all classrooms, more often in Ontario than Guanajuato) that examined examples of social conflict-potentially offering opportunities for guided practice and skill development in conflict analysis, such as identifying stakeholders and their positions and interests, probing contrasting perspectives, assessing causes of conflict escalation or war. The teacher guide of a course recently implemented in México, Civics and Ethics, encouraged student discussion on a range of social conflict issues. The lessons from that text that teachers described usually involved individual decision making, for instance at school L1 about "moral dilemma" scenarios, at school L2 about personal health care and "better" (legal) ways to earn money. Another Civics and Ethics lesson at L1 simulated an election campaign, only with invented platform issues and without a culminating vote or link to actual political news. A few teachers, mostly in Ontario, occasionally used role-plays to present and humanize contrasting viewpoints - for instance in Guanajuato school L3 about a rebellion episode in Mexican history and in Ontario about far-away human rights struggles. Most of these conflict examples were presented as non-controversial and/or removed in time or space (such as).

Risky conflicts - such as contemporary government policies, drug trafficking, or locally relevant inequity problems - were almost universally avoided in Guanajuato classrooms, and just occasionally addressed in some of the Ontario classrooms. Some Guanajuato teachers did address problems relevant to students' lives, such as 
migration - primarily as individual decisions (whether to travel to the USA to work), not addressing associated policy controversies. Others taught about the effects of natural disasters or pollution, and once or twice engaged students in clean up or recycling awareness campaigns. One or two teachers in most schools occasionally read children's literature in language arts classes, discussing characters' perspectives on conflicts in the stories. One Ontario (T2) teacher, uniquely, engaged his students in an extended inquiry project, interviewing family and community members about conflict issues, linked to comparing candidates' platforms in a mayoral election campaign. Other Ontario (T1) teachers engaged students in consumer inquiry regarding the manufacturing of their clothing in Pakistan and China. A few teachers (especially in Ontario) taught about human rights, primarily as lists of claims such as the UN Declaration and examples of violations in other parts of the world. Thus some of students' lived conflicts, and some more distant conflicts, occasionally were addressed in participants' classrooms - generally without creating much space for examining possibilities for collective decision making or action, nor for student self expression, emotional engagement, or dissent.

To understand and handle conflicts inclusively and equitably is a core capacity for both peacebuilding and democratic citizenship. However, conflict questions embedded in lesson subject matter and in students' lives were most often avoided, rarely taken up as learning opportunities. Teachers at all five schools did mention occasional opportunities to touch upon more complex and potentially democratic components of problem solving and peacebuilding. All the teachers described holding some classroom "discussions" or "debates" (sometimes simultaneously "teaching" their own opinions), usually one-time conversations disconnected from other subject matter.

Students, in their focus groups, concurred that some of conflict issues-especially those distanced from controversy, such as environment in Guanajuato or school bullying in Ontario-were mentioned or addressed briefly in some of their classrooms. They showed, through words and enthusiastic demeanor, that these moments of addressing conflicts usually were among their most interesting and valued lessons. However, most students also said that they had little opportunity to study or discuss conflict issues in any depth in class, nor to practice autonomous conflict management, and that some conflicts (and violence) they lived with were ignored entirely. Several students in most focus groups, especially in Guanajuato, articulated an optimistic narrative about the potential of education to contribute to democracy and peacebuilding. However, these narratives were primarily framed in terms of what education could accomplish, rather than grounded in descriptions of their own learning experiences, actually practicing what they hoped for.

Students in all focus groups said they wanted more opportunities to inquire about, to practice handling, and to express their own views about conflicts, including large-scale social issues as well as interpersonal disputes. Several students in most schools (in both cities) said that they wished for more lessons in how to resolve interpersonal conflicts before they escalated. They asked for more active learning pedagogies, community involvement activities, deeper and sustained discussions that would include their experience-based knowledge, and opportunities for creative expression through the arts.

\section{Discussion}

Schools, by no means the only educators in young people's lives, are one powerful site for learning in which young people living in violent surroundings carry much hope and spend much time. Because it is so highly valued, and because it can make a difference to people, formal education is a site for struggle among social and political goals - too often reinforcing the violent status quo, but sometimes nurturing capacities for democratic and peacebuilding transformation (Carnoy \& Samoff, 1990; Davies, 2011).

The rare moments in which teachers in the schools we visited had invited participating students' lived experiences and concerns about social conflicts into classrooms as learning resources - even indirectly, by discussing or role-playing the conflicts of others-evidently were among students' most memorable and valued school experiences. Most participating teachers seemed to love and care for their students, and certainly were very concerned about the cultures of violence surrounding each school. However, participants shared little evidence of teachers actually facilitating student learning, through practice and feedback, of the concepts and skills of conflict analysis, resolution and transformative action that are common to active democratic citizenship and to peacebuilding. Collective cultural, political and social dynamics of conflict and conflict handling were especially absent in their descriptions of experienced curriculum. Students' local communities were primarily understood, apparently by students as well as their teachers, as places of difficulty, need, and blame, rather than as repositories of lived citizenship resources - embodied by students, families, community leaders, and institutional actors - that might contribute to collective learning and solution-finding for the difficult problems they endured. 
Teachers participating in this research told facilitators that they were coming to realize that tangible, frequent democratic peace-building learning opportunities — subject matter and practice — could be embedded in their daily work and infused across the curriculum. Thereby broadening students' horizons, while attending to the "real" problems they live and care about, would provide access to constructive conflict education, encounters with democratic institutions and decision-making (spaces for democratic action), and motivation to engage. To develop capacity and confidence (agency) to act nonviolently and to make collective decisions requires practice with self-expression, including disagreement and encouragement of difference. Students participating in this research demonstrated their hope and idealism, amid often very challenging circumstances, and pointed the way toward public education that could better fulfill those hopes.

\section{References}

Aberdeen, Lucinda, \& Mariko Matthews, Julie. (1999). Judgements on Justice: young people and Aboriginal reconciliation. Race Ethnicity and Education, 2(2), 203-218. doi:10.1080/1361332990020203

Abrego, María Guadalupe. (2010). La situación de la educación para la paz en Mexico en la actualidad. Espacios Públicos, 2010(13), 149-164.

Acevedo Rodrigo, Ariadna, \& López Caballero, Paula. (2012). Ciudadanos inesperados : Espacios de formación de la ciudadanía ayer y hoy (Primera edición. ed.). México, D.F.: El Colegio de México : Centro de Investigación y de Estudios Avanzados.

Andere, Eduardo. (2013). La escuela rota : sistema y política en contra del aprendizaje en México (1. ed.). México, D.F.: Siglo Veintiuno Editores.

Aronson, Elliot. (2000). Nobody Left to Hate: Teaching Compassion after Columbine. New York: Worth Publishers.

Bartlett, Lesley. (2005). Dialogue, knowledge, and teacher-student relations: Freirean pedagogy in theory and practice. Comparative Education Review, 49(3), 344-364.

Barton, Keith. (2015). Young adolescents' positioning of human rights: Findings from Colombia, Northern Ireland, Republic of Ireland and the United States. Research in Comparative and International Education, 10(1), 48-70. doi:10.1177/1745499914567819

Barton, Keith, \& McCully, Alan. (2005). History, identity and the school curriculum in Northern Ireland: An empirical study of secondary students' ideas and perspectives. Journal of Curriculum Studies, 37(1), 85-116.

Bellino, Michelle. (2015). Civic engagement in extreme times: The remaking of justice among Guatemala's 'postwar' generation. Education, Citizenship and Social Justice, 10(2), 118-132. doi:10.1177/1746197915583937

Bickmore, Kathy. (2002). Peer mediation training and program implementation in elementary schools: Research results. Conflict Resolution Quarterly, 19(4).

Bickmore, Kathy. (2008). Peace and conflict education. In James Arthur, Ian Davies, \& Carole Hahn (Eds.), Sage Handbook of Education for Citizenship and Democracy (pp. 438-454). London, UK: Sage Publications.

Bickmore, Kathy. (2011a). Keeping, making, and building peace in school. Social Education ("Research and Practice" section), 75(1), 42-46.

Bickmore, Kathy. (2011b). Policies and programming for safer schools: Are 'anti-bullying' approaches impeding education for peacebuilding? Educational Policy, 25(4), 648-687.

Bickmore, Kathy. (2014). Peace-building dialogue pedagogies in Canadian classrooms. Curriculum Inquiry, 44(4), 553582.

Bickmore, Kathy. (forthcoming 2017). Conflict, Peace-building, and Education: Rethinking Pedagogies in Divided Societies, Latin America, and around the World. In Kathy Bickmore, Ruth Hayhoe, Caroline Manion, Karen Mundy, \& Robyn Read (Eds.), Comparative and International Education: Issues for Teachers (Second, revised and expanded ed.). Toronto: Canadian Scholars Press.

Bickmore, Kathy, \& Parker, Christina A. (2014). Constructive conflict talk in classrooms: Divergent approaches to addressing divergent perspectives. Theory and Research in Social Education, 42(4), 291-335.

Bush, Kenneth, \& Saltarelli, Diana. (2000). The Two Faces of Education in Ethnic Conflict: Towards a Peacebuilding Education for Children. Retrieved from Florence, IT: https://www.unicefirc.org/publications/pdf/insight4.pdf

Carnoy, Martin, \& Samoff, Joel. (1990). Education and Social Transformation: Theory and Practice. In M Carnoy \& J Samoff (Eds.), Education and Social Transition in the Third World (pp. 361-380). Princeton: Princeton University Press.

Chareka, Ottilia, \& Sears, Alan. (2005). Discounting the political: understanding civic participation as private practice. Canadian and International Education, 34(1), 50-58. 
Chareka, Ottilia, \& Sears, Alan. (2006). Civic duty: young people's conceptions of voting as a means of political participation. Canadian Journal of Education, 29(2), 521-540.

Charmaz, Kathy. (2000). Grounded theory: objectivist and constructivist methods. In N. Denzin \& Y. Lincoln (Eds.), Handbook of Qualitative Research (2nd ed., pp. 509-535). Thousand Oaks, CA: Sage Publications.

Costandius, Elmarie, \& Bitzer, Eli. (2014). Opening up spaces for social transformation: Critical citizenship education in a post-conflict South African university context. Education, Citizenship and Social Justice, 9(2), 128-139.

Cox, Cristián, Bascopé, Martín , Castillo, Juan Carlos, Miranda, Daniel , \& Bonhomme, Macarena. (2014). Educación ciudadana en América Latina: Prioridades de los currículos escolares. Retrieved from Geneva: http://www.ibe.unesco.org/en/services/online-materials/publications/ibe-working-papers.html

Daniel, Yvette, \& Bondy, Karla. (2008). Safe Schools and Zero Tolerance: Policy, Program and Practice in Ontario. Canadian Journal of Educational Administration and Policy(70).

Davies, Lynn. (2005). Teaching about conflict through citizenship education. International Journal of Citizenship and Teacher Education, 1(2), 17-34.

Davies, Lynn. (2011). Can education interrupt fragility? Toward the resilient citizen and the adaptable state. In Karen Mundy \& Sarah Dryden-Peterson (Eds.), Educating Children in Conflict Zones: Research, Policy and Practice for Systemic Change-A Tribute to Jackie Kirk (pp. 33-48). New York: Teachers College Press.

Diazgranados, Silvia. (2014). How students' perceptions of the school climate influence their choice to upstand, bystand, or join perpetrators of bullying. Harvard Educational Review, 84(2).

Diazgranados, Silvia, \& Noonan, James. (2015). The relationship of safe and participatory school environments and supportive attitudes toward violence: Evidence from the Colombian Saber test of Citizenship Competencies. Education, Citizenship and Social Justice, 10(1), 79-94.

Farrell, Joseph, Manion, Caroline, \& Rincón-Gallardo, Santiago. (forthcoming 2017). Reinventing schooling: Successful radical alternatives from the global south. In Kathy Bickmore, Ruth Hayhoe, Caroline Manion, Karen Mundy, \& Robyn Read (Eds.), Comparative and International Education: Issues for Teachers (2nd ed.). Toronto: Canadian Scholars Press.

Festinger, Leon. (1964). Conflict, Decision, and Dissonance. Stanford, CA: Stanford University Press.

Freire, Paulo. (1994). Pedagogy of hope

. London: Continuum.

Goldberg, Tsafrir, \& Ron, Yiftach. (2013). 'Look, each side says something different': the impact of competing history teaching approaches on Jewish and Arab adolescents' discussions of the Jewish-Arab conflict. Journal of Peace Education, 11(1), 1-29.

Guevara, G., \& Tirado, F. . (2006). Conocimientos cívicos en Mexico: Un estudio comparativo internacional. Revista Mexicana de Investigación Educativa (Consejo Mexicano de Investigación Educativa), 11(30), 995-1018.

Harris, Robert. (2005). Unlocking the learning potential in peer mediation: An evaluation of peer mediator modeling and disputant learning. Conflict Resolution Quarterly, 23(2), 141-164.

Hughes, Andrew, Print, Murray, \& Sears, Alan. (2010). Curriculum capacity and citizenship education: a comparative analysis of four democracies. Compare: A Journal of Comparative and International Education, 40(3), 293-309.

Hughes, Andrew, \& Sears, Alan. (2008). The struggle for citizenship education in Canada: the centre cannot hold. In James Arthur, Ian Davies, \& Carole Hahn (Eds.), Sage Handbook of Education for Citizenship and Democracy (pp. 124-138). London: Sage Publications.

IEP, Institute for Economics and Peace. (2015). Mexico Peace Index 2015: Analyzing the Changing Dynamics of Peace in Mexico. Retrieved from Mexico City: economicsandpeace.org

Jones, Tricia. (2004). Conflict resolution education: the field, the findings, and the future. Conflict Resolution Quarterly, 22(1-2), 233-267.

Kahne, Joseph, \& Sporte, Susan. (2008). Developing citizens: the impact of civic learning opportunities on students' commitment to civic participation. American Educational Research Journal, 45(3), 738 - 766.

Kallio, Kirsi Pl, Häkli, Jouni, \& Bäcklund, Pia. (2015). Lived citizenship as the locus of political agency in participatory policy. Citizenship Studies, 19(1), 101-119.

Keddie, Amanda. (2014). Students' understandings of religious identities and relations: Issues of social cohesion and citizenship. Education, Citizenship and Social Justice, 9(1), 81-93.

Kennelly, Jacqueline, \& Dillabough, Jo-Anne. (2008). Young people mobilizing the language of citizenship: struggles for classification and new meaning in an uncertain world. British Journal of Sociology of Education, 29(5), 493508.

Khalaf, Roseanne Saad. (2014). Lebanese youth narratives: a bleak post-war landscape. Compare: A Journal of Comparative and International Education, 44(1), 97-116. doi:10.1080/03057925.2013.859899

Lederach, John Paul. (1995). Preparing for peace: Conflict transformation across cultures. Syracuse: Syracuse University Press.

Lederach, John Paul. (2003). The Little Book of Conflict Transformation. Intercourse, PA: Good Books. 
Levesque, Stephane. (2003). 'Bin Laden is responsible; it was shown on tape': Canadian high school students' historical understanding of terrorism. Theory \& Research in Social Education, 31(2), 174-202. doi:10.1080/00933104.2003.10473221

Llewellyn, Kristina, \& Westheimer, Joel. (2009). Beyond facts and acts: the implications of 'ordinary politics' for youth political engagement. Citizenship Teaching and Learning, 5(2), 50-61.

McCauley, Clark. (2002). Head first versus feet first in peace education. In G. Salomon \& B. Nevo (Eds.), Peace Education: The concept, principles, and practices around the world (pp. 247-258). Mahwah, NJ: Lawrence Erlbaum Associates.

Merelman, Richard. (1990). The role of conflict in children's political learning. In O. Ichilov (Ed.), Political socialization, citizenship education, and democracy (pp. 47-65). New York: Teachers College Press.

Meyer, John W., Bromley, Patricia, \& Ramirez, Francisco. (2010). Human rights in social science textbooks: Crossnational analysis, 1970-2008. Sociology of Education, 83(4), 111-134.

Morrison, Brenda, \& Vaandering, Dorothy. (2012). Restorative Justice: Pedagogy, Praxis, and Discipline. Journal of School Violence, 11(2), 138-155.

Nagda, Biren Ratnesh, \& Gurin, P. (2007). Inter-group dialogue: A critical-dialogic approach to learning about difference, inequality, and social justice. New Directions for Teaching and Learning, 111, 35-45.

Ornelas, Carlos. (2013). The Mexican Education System (El sistema educativo mexicano: la transición de fin de siglo)second, revised edition.

Pearce, Jenny. (2010). Perverse state formation and securitized democracy in Latin America. Democratization, 17(2), 286-306. doi:10.1080/13510341003588716

Peetz, Peter. (2011). Youth violence in Central America: Discourses and policies. Youth and Society, 43(4), 1459-1498.

Quaynor, Laura. (2012). Citizenship education in post-conflict contexts: A review of the literature. Education, Citizenship and Social Justice, 7(1), 33-57. doi:10.1177/1746197911432593

Quaynor, Laura. (2014). 'I do not have the means to speak:' educating youth for citizenship in post-conflict Liberia. Journal of Peace Education, 12(1), 15-36. doi:10.1080/17400201.2014.931277

Reimers, Fernando, \& Cardenas, Sergio. (2010). Youth Civic Engagement in Mexico Handbook of Research on Civic Engagement in Youth (pp. 139-160): John Wiley \& Sons, Inc.

Reimers, Fernando, Ortega, Maria Elena, Cardenas, Mariali, Estrada, Armando, \& Garza, Emanuel. (2014). Empowering Teaching for Participatory Citizenship: Evaluating the Impact of Alternative Civic Education Pedagogies on Civic Attitudes, Knowledge and Skills of Eight-grade Students in Mexico. Journal of Social Science Education, 13(4), 41-55. doi:10.2390/jsse-v13-i4-1357

Reimers, Fernando, \& Villegas-Reimers, Eleonora. (2006). Sobre la calidad de la educación y su sentido democrático. Revista Proyecto Regional de Educación para América Latina y el Caribe(2), 91-107.

Ridley, Rebecca, \& Fulop, Marta. (2015). Young Hungarians' constructions of active citizenship: Theoretical models and real-world voices. Citizenship Teaching \& Learning, 10(1), 25-41.

Rincón-Gallardo, Santiago, \& Elmore, Richard. (2012). Transforming Teaching and Learning Through Social Movement in Mexican Public Middle Schools. Harvard Educational Review, 82, 471-490.

Ross, Marc Howard. (1993). The Management of Conflict: Interpretations and Interests in Comparative Perspective. New Haven: Yale University Press.

Ross, Marc Howard. (2010). Peace education and political science. In Gavriel Salomon \& Ed Cairns (Eds.), Handbook of Peace Education (pp. 121-133). NY: Psychology Press/ Taylor \& Francis.

Salomon, Gavriel, \& Nevo, Baruch (Eds.). (2002). Peace Education: The Concept, Principles, \& Practices around the World. Mahwah, NJ: Lawrence Erlbaum Associates.

Santizo Rodall, Claudia, \& Martin, Christopher. (2009). School-based management and citizen participation: Lessons for public education from local educational projects. Journal of Education Policy, 24(3), 317-333.

Schulz, Wolfram, Ainley, John, Fraillon, Julian, Kerr, David, \& Losito, Bruno. (2010). ICCS 2009 International Report: Civic knowledge, attitudes and engagement among lower secondary school students in thirty-eight countries. Amsterdam: http://www.iea.nl/fileadmin/user_upload/Publications/Electronic_versions/ICCS_2009_International_Repor t.pdf

Schulz, Wolfram, Ainley, John, Friedman, T., \& Lietz, P. . (2011). ICCS 2009 Latin American Report: Civic knowledge and attitudes among lower-secondary students in six Latin American countries. Retrieved from Amsterdam:

Seixas, Peter, Peck, Carla L., \& Poyntz, Stuart. (2011). 'But we didn't live in those times': Canadian students negotiate past and present in a time of war. Education as Change, 15(1), 47-62.

Skiba, Russell, \& Peterson, R. (1999). The dark side of zero tolerance: Can punishment lead to safe schools? Phi Delta Kappan, January, 372-382.

Suárez, David. (2008). Rewriting citizenship? Civic education in Costa Rica and Argentina. Comparative Education, 44(4), 485-503. 
Tapia, Medardo (et. al.). (2003). Formación cívica en México: 1990-2001. In María Bertely (Ed.), Educación, derechos sociales y equidad, Vol. III (pp. 987-1005). México City, Mexico: Consejo Mexicano de Investigación Educativa.

Tibbitts, Felicia, \& Torney-Purta, Judith. (1999). Citizenship education in Latin America: Preparing for the future. Washington, DC: Human Rights Education Associates.

Tobin, Joseph. (1999). Method and meaning in comparative classroom ethnography. In Robin Alexander (Ed.), Learning from Comparing (pp. 113-134). Oxford, UK: Symposium Books.

Torney-Purta, Judith, \& Amadeo, JoAnn. (2011). Participatory Niches for Emergent Citizenship in Early Adolescence: An International Perspective. ANNALS of the American Academy of Political and Social Science, 633(1), 180200.

Tupper, Jennifer, \& Cappello, Michael. (2012). (Re)Creating citizenship: Saskatchewan high school students' understandings of the 'good' citizen. Journal of Curriculum Studies, 44(1), 37-59.

Tupper, Jennifer, Cappello, Michael, \& Sevigny, Phillip. (2010). Locating Citizenship: Curriculum, Social Class, and the 'Good' Citizen. Theory \& Research in Social Education, 38(3), 336-365. doi:10.1080/00933104.2010.10473430

Werner, Walter. (1997). Teaching for hope. In R. Case \& P. Clark (Eds.), The Canadian Anthology of Social Studies (pp. 249-253). Burnaby, BC: Faculty of Education, Simon Fraser University.

Werner, Walter. (2002). Teaching about sectarian violence reported through the media. Canadian Social Studies, 37(1), on-line edition. 